\title{
KAJIAN RESIKO PENGGUNAAN OBAT YANG HARUS DIGUNAKAN DENGAN HATI-HATI PADA PASIEN GERIATRI DENGAN DIAGNOSIS GANGGUAN SARAF BERDASARKAN BEERS CRITERIA
}

\author{
EVALUATION OF DRUG USAGE RISK THAT MUST BE USED \\ CAREFULLY IN GERIATIC PATIENTS WITH DIAGNOSIS OF NERVOUS \\ DISORDERS BASED ON BEERS CRITERIA
}

\author{
Indriastuti Cahyaningsih*, Novi Amaliya \\ Program Studi Profesi Apoteker, Fakultas Kedokteran dan Ilmu Kesehatan \\ Universitas Muhammadiyah Yogyakarta \\ *Penulis Korespondensi, email : ndree_chy@yahoo.com
}

\begin{abstract}
ABSTRAK
Pasien geriatri umumnya mengalami kerentanan terhadap berbagai macam penyakit karena menurunnya fungsi organ tubuh salah satunya adalah gangguan saraf. Ketidaktepatan penggunaan obat-obat yang bekerja pada sistem saraf berdasarkan Beers Criteria 2015 banyak dilaporkan. Penelitian ini dilakukan untuk mengetahui prevalensi resiko ketidaktepatan peresepan obat dengan diagnosis gangguan saraf pada pasien geriatri rawat inap berdasarkan Beers Criteria 2015 pada kategori obat yang harus digunakan dengan hatihati di Rumah Sakit Umum Daerah Panembahan Senopati Bantul. Penelitian ini merupakan penelitian observasional dan pengumpulan data dilakukan secara retrospektif berdasarkan data rekam medik pasien geriatri dengan diagnosis gangguan saraf di instalasi rawat inap RSUD Panembahan Senopati Bantul periode Januari - Desember 2016. Pengambilan sampel dilakukan secara systematic random sampling. Data dikumpulkan dari 153 rekam medik pasien yang masuk kriteria inklusi. Data dianalisis berdasarkan guideline American Geriatrics Society Beers Criteria 2015. Hasil penelitian menunjukkan bahwa dari 153 pasien geriatri di RSUD Panembahan Senopati Bantul yang masuk dalam kriteria inklusi terdapat 85 pasien $(55,6 \%)$ teridentifikasi Potentially Inappropiate Medications (PIMs). Potentially Inappropiate Medications yang termasuk pada kategori obat yang digunakan dengan hati-hati pada pasien geriatri persentase terbanyak yaitu furosemid sebanyak 37 penggunaan $(71,2)$ diikuti dengan manitol 13,5\%, klorpromazin (5,8\%), haloperidol (3.8\%), sedangkan spironolakton, fluoxetine dan amitriptilin masing-masing adalah $1.9 \%$.
\end{abstract}

Kata kunci : geriatri, potentially inappropriate medications, Beers Criteria 2015, gangguan saraf

\section{ABSTRACT}

Geriatric patients generally experience susceptibility to various diseases because of the decline in the function of organs, one of which is neurological disorders. The inaccuracy of the use of drugs acting on the nervous system based on the Beers Criteria 2015 has been widely reported. This study was conducted to determine the prevalence of the risk of 
inaccurate prescribing of drugs with the diagnosis of neurological disorders in hospitalized geriatric patients based on the Beers Criteria 2015 in the category of drugs that must be used with caution in Panembahan Senopati Regional General Hospital Bantul. This study was an observational study and data collection was done retrospectively based on medical record data of geriatric patients with a diagnosis of neurological disorders hospitalized at Panembahan Senopati General Hospital Bantul for the period January - December 2016. Sampling was carried out by systematic random sampling. Data were collected from 153 medical records of patients who entered the inclusion criteria. Data were analyzed based on the 2015 American Geriatrics Society's Beers Criteria Society guideline. The results showed that of 153 geriatric patients in Panembahan Senopati General Hospital Bantul included in the inclusion criteria there were 85 patients (55.6\%) identified as Potentially Inappropriate Medications (PIMs). Potentially Inappropriate Medications included in the category of medications used with caution in geriatric patients the highest percentage was 37 furosemides (71.2) followed by mannitol 13.5\%, chlorpromazine (5.8\%), haloperidol (3.8\%) while spironolactone, fluoxetine, and amitriptyline were $1.9 \%$ respectively.

Keywords: geriatric, potentially inappropriate medications, Beers Criteria 2015, nervous disorder

\section{PENDAHULUAN}

World Health Organization (WHO) mengklasifikasikan berdasarkan tingkatan usia yaitu pada usia pertengahan (middle age) antara 45 sampai 59 tahun, lanjut usia (elderly) antara 60-74 tahun, lanjut usia tua (old) antara 75-90 tahun, dan usia sangat tua (very old) di atas 90 tahun. Data dari Kemenkes RI menunjukkan bahwa dari persebaran penduduk usia lanjut dengan prevalensi terbanyak pada provinsi DIY dan terendah terdapat di Papua. Usia lanjut ditandai dengan menurunnya fungsi organ tubuh yang dapat mengakibatkan rentannya terhadap berbagai macam penyakit seperti penyakit kardiovaskular, penyakit sistem saraf, dan penyakit lainnya. Hal tersebut disebabkan karena perubahan fungsi organ, struktur, jaringan, dan sistem organ sehingga berpengaruh terhadap kemunduran kesehatan fisik dan psikis (Fatimah, 2010).

Peningkatan penggunaan obat yang tidak tepat merupakan masalah yang serius karena dapat meningkatkan morbiditas, mortalitas, dan biaya kesehatan (AS et al., 2015). Pada penelitian yang dilakukan Anjum dkk obat-obat yang paling umum diresepkan yaitu obat-obat kardiovaskular (14,62\%), kemudian diikuti obat-obat Sistem Saraf Pusat (SSP) (14,09\%), sedangkan penggunaan PIMs yang sering diresepkan untuk gangguan SSP diikuti dengan gangguan kardiovaskular (Anjum et al., 2017).

Rawat inap merupakan salah satu faktor resiko terjadinya ketidaktepatan dalam penggunaan obat pada geriatri (Endres et al., 2016). Berdasarkan data dari hasil penelitian tersebut ketidaktepatan penggunaan obat pada sistem saraf seperti obat golongan benzodiazepin, selective serotonin reuptake inhibitor (SSRI), dan Tricyclic Antidepressant (TCA) banyak terjadi sehingga potensi ketidaktepatan penggunaan obat-obat dengan diagnosis saraf terhadap pasien geriatri perlu diperhatikan. Penelitian yang dilakukan oleh Harugeri dkk melaporkan bahwa $\geq 10$ hari dikaitkan dengan kemungkinan penggunaan obat yang tidak tepat (Harugeri et al., 2010). Hal ini disebabkan hubungan yang proporsional antara lama inap dengan jumlah obat yang diresepkan. 
Beers criteria merupakan salah satu metode yang dapat digunakan untuk menilai ketidaksesuaian penggunaan obat dan obat-obat yang masih bisa digunakan namun memerlukan perhatian khusus pada pasien geriatri. Pada tahun 2015, Beers criteria diperbaharui oleh American Geriatrics Society (AGS) bekerjasama dengan 13 ahli panel dibidang perawatan geriatri dan farmakoterapi. Dalam Beers criteria 2015 menggolongkan menjadi 5 kategori ketidaktepaatan obat yaitu obat-obat yang harus dihindari pada sebagian besar lanjut usia berdasarkan organ sistem, obat yang harus dihindari dengan penyakit atau sindrom khusus, obat-obat berinteraksi yang harus dihindari penggunaannnya, obat yang digunakan dengan hati-hati, dan obat yang harus disesuaikan dosisnya berdasarkan fungsi ginjal individu. Penelitian ini diharapkan dapat memberikan gambaran mengenai hasil evaluasi peresepan obat dengan diagnosis gangguan saraf pada pasien geriatri rawat inap di RSUD Panembahan Senopati Bantul periode tahun 2016 khususnya pada kategori obat yang harus digunakan dengan hati-hati berdasarkan Beers criteria 2015 (American Geriatrics Society, 2015).

\section{METODOLOGI PENELITIAN}

Alat dan bahan

Data rekam medik pasien sebagai informasi riwayat pengobatan yang diterima oleh pasien geriatri dan American Geriatics Society Beers criteria 2015 sebagai panduan yang digunakan untuk mengidentifikasi ketidaksesuaian penggunaan obat pada geriatri.

\section{Jalannya penelitian}

Penelitian ini merupakan penelitian observasional dengan metode pengambilan data secara retrospektif berdasarkan data rekam medik pasien yang berusia $\geq 60$ tahun dengan diagnosis saraf dengan atau tanpa penyakit penyerta yang menjalani rawat inap di RSUD Panembahan Senopati Bantul periode Januari - Desember 2016. Jumlah sampel yang digunakan pada penelitian ini sebanyak 153 pasien lanjut usia.

Teknik pengambilan sampel dalam penelitian ini adalah systematic random sampling. Identifikasi ketepatan obat dilakukan berdasarkan guideline Beers criteria 2015 pada kategori obat yang harus digunakan secara hati-hati dan dianalisis secara deskriptif. Penyajian data secara kualitatif dan kuantitatif dalam bentuk persentase.

\section{HASIL DAN PEMBAHASAN}

Karakteristik Data Pasien

Penelitian ini terdapat 153 sampel yang memenuhi kriteria inklusi. Karakteristik pasien digolongkan berdasarkan kategori usia dan jenis kelamin. Detail karakteristik data pasien ditujukkan pada Tabel I. 
Tabel I. Karakteristik data pasien

\begin{tabular}{lcc}
\hline Karakteristik & $\begin{array}{c}\text { Jumlah n } \\
\mathbf{1} \mathbf{1 5 3}\end{array}$ & $\begin{array}{c}\text { Presentase } \\
(\mathbf{\%})\end{array}$ \\
\hline Jenis Kelamin & & \\
\hline Laki-laki & 84 & 54,9 \\
Perempuan & 69 & 45,1 \\
\hline Kelompok Usia & & \\
\hline 60-74 tahun & 96 & 62,7 \\
$\mathbf{7 5 - 9 0}$ tahun & 56 & 36,6 \\
$>\mathbf{9 0}$ tahun & 1 & 0,7 \\
\hline
\end{tabular}

Berdasarkan data distribusi pasien geriatri kasus saraf di RSUD Panembahan Senopati Bantul dengan karakteristik jenis kelamin didapatkan hasil bahwa pasien geriatri laki-laki sebanyak 84 pasien (55\%) lebih banyak dari pada pasien geriatri perempuan yaitu sebanyak 69 pasien (45\%). Hal ini menunjukkan bahwa kejadian penyakit saraf pada geriatri didominasi oleh laki-laki. Faktor resiko berbagai penyakit saraf salah satunya adalah jenis kelamin (Ikawati, 2014).

Distribusi pasien berdasarkan usia pada penelitian ini menunjukkan bahwa distribusi pada usia 60-74 tahun sebanyak 96 pasien $(62,7 \%)$, sedangkan paling sedikit yaitu pada usia > 90 tahun sebanyak 1 pasien $(0,7 \%)$. Pada penyakit saraf, usia merupakan faktor resiko yang terpenting pada geriatri, dengan seiring bertambahnya usia menjadi salah satu faktor berkurangnya kemampuan tubuh untuk memperbaiki diri termasuk kemampuan fungsi otak, fungsi tulang seperti pada kondisi penyakit low back pain (Ikawati, 2014).

\section{A. Gambaran Diagnosis Pasien}

Hasil penelitian menunjukkan bahwa distribusi diagnosis pasien pada penelitian ini terdapat tiga diagnosis terbesar yaitu diagnosis stroke $(51,6 \%)$, diikuti dengan hemiplegia $(17,0 \%)$ dan dizziness and giddiness $(9,8 \%)$. Distribusi diagnosis pasien ditunjukkan pada Tabel II.

Tabel II menunjukkan bahwa stroke merupakan diagnosis utama terbesar pasien (51.6\%) diikuti oleh hemiplegia (17,0\%) dan sakit kepala (9,8\%). Hasil riset kesehatan dasar tahun 2018 menyatakan bahwa stroke termasuk penyakit tidak menular dengan prevalensi mencapai 14,7 per seribu penduduk di Propinsi Daerah Istimewa Yogyakarta yang menduduki peringkat ke 2 setelah propinsi Kalimantan Timur. 
Tabel II. Distribusi diagnosis pasien geriatri dengan diagnosis saraf

\begin{tabular}{rlcc}
\hline No & \multicolumn{1}{c}{ Diagnosis } & Frekuensi & Persentase (\%) \\
\hline 1 & Stroke & 79 & 51.6 \\
2 & Hemiplegia & 26 & 17.0 \\
3 & Dizziness & 15 & 9.8 \\
4 & Epilepsi & 8 & 5.2 \\
5 & Intracerebral Haemorrhage & 6 & 3.9 \\
6 & Mononeuropathy & 3 & 2.0 \\
7 & Parkinson & 3 & 2.0 \\
8 & Demensia & 3 & 2.0 \\
9 & Cerebral Infarction & 2 & 1.3 \\
10 & Transient Cerebral Ischaemic Attacks & 2 & 1.3 \\
11 & Cervicobrachial Syndrome & 2 & 1.3 \\
12 & Disorder of Brain, Unspecified & 2 & 1.3 \\
13 & Intracranial Space-Occupying Lesion & 1 & 0.7 \\
14 & Low Back Pain & 1 & 0.7 \\
\hline & $\quad$ Jumlah & 153 & 100.0 \\
\hline
\end{tabular}

B. Gambaran Terapi Pasien

Penelitian ini mengikutsertakan 153 pasien yang memiliki diagnosis utama pada gangguan saraf dengan atau tanpa penyakit penyerta. Gambaran terapi yang digunakan pasien ditunjukkan pada Tabel III.

Tabel III menunjukkan bahwa penggunaan neuroprotektan mencapai 182 pasien dimana persentase terbesar adalah penggunaan citicolin yakni mencapai 121 pasien. Hal ini berhubungan dengan diagnosis utama dari pasien yakni stroke, dimana pengguaan neuroprotektan banyak diresepkan. Terapi pada stroke iskemik sebaiknya dilakukan secara kombinasi untuk mendapatkan hasil yang optimal. Kombinasi terapi antara terapi trombolitik dan neuroprotektif telah terbukti efektif jika dibandingkan dengan monoterapi (Ginsberg, 2008). Pemberian neuroprotektan harus mempertimbangkan aspek positif dan negatif dari respon stroke. Hal ini untuk memastikan bahwa pasien diberikan dalam kondisi yang tepat dan menghasilkan manfaat yang optimal (Majid, 2014). 
Tabel III. Gambaran terapi pasien dengan gangguan saraf

\begin{tabular}{|c|c|}
\hline Golongan Obat & $\begin{array}{c}\text { Jumlah Pasien yang } \\
\text { Menggunakan }\end{array}$ \\
\hline Diuretik & 37 \\
\hline Antibiotik & 77 \\
\hline Nitrat & 12 \\
\hline $\mathrm{CCB}$ & 54 \\
\hline ARB & 94 \\
\hline Beta blocker & 7 \\
\hline ACEI & 4 \\
\hline Antiaritmia & 2 \\
\hline Glikosida jantung & 2 \\
\hline H2 bloker & 64 \\
\hline Antihistamin & 5 \\
\hline Insulin & 8 \\
\hline Biguanid & 11 \\
\hline Sulfonilurea & 3 \\
\hline Antiulcer & 6 \\
\hline Antiemetik & 4 \\
\hline PPI (Proton Pump Inhibitor) & 43 \\
\hline Antagonis Serotonin & 2 \\
\hline Fibrat & 7 \\
\hline Statin & 21 \\
\hline NSAID & 42 \\
\hline Antipiretik & 19 \\
\hline Analgesik opiate & 5 \\
\hline Mukolitik ekspektoran & 5 \\
\hline Antitusif & 1 \\
\hline Antijamur & 4 \\
\hline Penghambat xantin oksidase & 2 \\
\hline Kortikosteroid & 6 \\
\hline Antikoagulan & 21 \\
\hline Vasodilator & 3 \\
\hline Agonis dopamin & 2 \\
\hline Benzodiazepin & 32 \\
\hline Antipsikotik & 8 \\
\hline SSRI & 1 \\
\hline TCA & 1 \\
\hline Adsorben & 7 \\
\hline Antiepilepsi & 28 \\
\hline Bronkodilator & 5 \\
\hline Suplemen & 45 \\
\hline Neuroprotektan & 182 \\
\hline Albumin & 3 \\
\hline Alpha bloker & 1 \\
\hline Relaksan otot & 1 \\
\hline Anti fibrinolitik & 1 \\
\hline
\end{tabular}


C. Kajian Ketidaktepatan Penggunaan Obat

Penelitian ini mengidentifikasi ketidaktepatan penggunaan obat pada pasien geriatri dengan kategori obat yang digunakan dengan hati-hati. Pengkajian ketepatan penggunaan obat pada penelitian ini menggunakan guideline American Geriatrics Society Beers criteria tahun 2015 yang merupakan guideline untuk mengidentifikasi Potentially Inappropiate Medication (PIMs) pada pasien geriatri. Hasil analisis pada penelitian ini ditunjukkan pada Tabel II.

Tabel IV. PIMs Obat-obat yang digunakan dengan hati-hati

\begin{tabular}{lcc}
\hline \multicolumn{1}{c}{ Nama Obat } & Frekuensi & $\begin{array}{c}\text { Persentase } \\
(\mathbf{\%})\end{array}$ \\
\hline Furosemid & 37 & 71,2 \\
Manitol & 7 & 13,5 \\
Klorpromazin & 3 & 5,8 \\
Haloperidol & 2 & 3,8 \\
Spironolakton & 1 & 1,9 \\
Fluoxetin & 1 & 1,9 \\
Amitriptilin & 1 & 1,9 \\
\hline \multicolumn{1}{c}{ Total } & $\mathbf{5 2}$ & $\mathbf{1 0 0}$ \\
\hline
\end{tabular}

Tabel IV menunjukkan bahwa untuk kategori obat-obatan yang harus digunakan dengan hati-hati frekuensi terbanyak pada penggunaan obat diuretik furosemid sebanyak 37 penggunaan $(71,2 \%)$ diikuti manitol sebanyak 7 penggunaan $(13,5 \%)$ diikuti dengan klorpromazin $(5,8 \%)$ sedangkan haloperidol, spironolakton dan amitriptilin masing-masing adalah 1,9\%. Furosemid merupakan golongan obat diuretik kuat. Penggunaannya diindikasikan pada kondisi udem karena penyakit jantung, hati, dan ginjal, selain itu sebagai terapi tambahan pada udem pulmonari akut dan udem otak yang diharapkan dapat mendapatkan onset terapi yang cepat (Pionas, 2018). Pemberian obat furosemid dapat menyebabkan hiponatremia sehingga dalam penggunaannya harus dilakukan monitoring kadar natrium secara ketat saat memulai atau mengubah dosis pada pasien geriatri (American Geriatrics Society Beers criteria, 2015).

Manitol dapat digunakan pada pasien dengan edema serebral dengan dosis $1 \mathrm{~g} / \mathrm{kg}$ sebagai larutan $20 \%$ dengan diberikan melewati infus intravena dengan kecepatan yang cepat (Pionas, 2018). Penelitian lain yang dilakukan di RSU Dr Saiful Anwar Malang penggunaan diuretik tunggal yaitu infus manitol pada pasien stroke iskemia juga banyak diresepkan (Astutik., 2013). Manitol dikontraindikasikan pada pasien yang mengalami gangguan fungsi ginjal dengan nilai Blood Urea Nitrogen (BUN) dan kreatinin tinggi (Rahajeng, 2007). Namun manitol digunakan sebagai standar terapi pada pasien dengan hipertensi intrakranial dan pada indikasi lain diantaranya untuk perlindungan ginjal selama operasi jantung atau sebagai profilaksis gagal ginjal akut pada kondisi rabdomiolisis dan setelah transplantasi ginjal (Shawkat et al., 2012). Pemberian obat pada geriatri harus memperhitungkan faal ginjal sebagai organ yang mengekskresikan sisa obat yang akan berdampak pada kemungkinan terakumulasinya obat yang dapat menimbulkan efek toksik. Patokan pemberian dosis obat dapat dilihat dari nilai waktu paruhnya (t1/2) obat tersebut (Departemen Kesehatan RI, 2006). 
Haloperidol sering digunakan untuk delirium yang dapat menyebabkan efek samping diantaranya adalah perpanjangan gelombang QT yang berhubunagn dengan meningkatnya resiko aritmia. Frekuensi penggunaan haloperidol untuk lansia mencapai 5,4\%, sehubungan dengan hal tersebut pelaporan adverse event di rumah sakit harus dilakukan secara sistematis (Nijboer, 2016). Haloperidol dilaporkan dapat meningkatkan kematian dibandingkan dengan risperidon atau quetiapine ketika digunakan untuk lansia. Resiko meningkatnya mortalitas berhubungan dengan penggunaan dosis yang tinggi (Huybrechts, 2012).

Spironolakton banyak diberikan kepada pasien dengan gangguan gagal jantung. Spironolakton ditoleransi baik namun tidak meningkatkan fungsi fisik lansia. Kualitas hidup meningkat secara signifikan (Burton, 2013). Spironolakton dosis rendah dapat menurunkan resiko kematian dari gagal jantung. Spironolakton saat diresepkan kepada lansia dengan $\mathrm{CHF}$, kejadian hiperkalemia sering terjadi. Pasien lansia yang memulai terapi dengan spironolakton harus dimonitor kadar serum potasium secara berkala (Butler, 2013). Pasien dengan usia $\geq 75$ tahun yang diterapi dengan spironolakton dikombinasikan dengan ACE inhibitor dan diuretik dilaporkan memicu insufisiensi renal $(>50 \%$ nilai kreatinin meningkat) yakni mencapai 37, 5\% dan 36\% berkembang ke hiperkalemia dan $11 \%$ berkembang menjadi hiperkalemia yang parah. Adverse event dapat diminimalisir dengan monitoring ketat selama terapi (Dinsdale, 2012).

Fluoxetine merupakan salah satu contoh obat golongan Selective Serotonin Reuptake Inhibitor (SSRI) yang banyak digunakan untuk pasien depresi. Efek samping yang dapat muncul dari penggunaan SSRI diantaranya adalah mual, mulut kering, insomnia, agitasi, diare, keringat berlebih dan disfungsi seksual. Hiponatremia merupakan efek samping potensial yang serius pada penggunaan SSRI pada pasien lanjut usia. Penggunaan bersama dengan obat diuretik perlu diperhatikan. Beberapa faktor resiko penyebab hiponatremia diantaranya adalah meningkatnya usia, jenis kelamin perempuan dan riwayat hiponatremia sebelumnya (Heron ,J.W, 2018). Perlu dicek untuk level natrium 1 bulan setelah memulai terapi dengan SSRI, khususnya pasien yang sedang menggunakan obat yang dapat menyebabkan hiponatremia misalnya diuretik. Fluoxetine tidak direkomendasikan untuk lansia karena $t^{1} / 2$ eliminasi yang panjang dan efek samping yang diperpanjang. SSRI yang memiliki profil keamanan yang baik jika digunakan untuk lansia diantaranya adalah citalopram, escitalopram dan sertraline (Wiese., 2011).

Amitriptilin termasuk antidepresan yang banyak digunakan. Amitriptilin merupakan jenis tertiary amine tricyclic yang dilaporkan efektif pada pasien depresi namun terkait dengan efek samping potensial yang ditimbulkan tidak disarankan digunakan untuk lansia (Varma., S, 2010). Efek samping yang dilaporkan akan lebih berat jika digunakan untuk pasien lanjut usia diantaranya adalah sedasi, efek antikolinergik, dan efek samping pada jantung serta resiko terjadinya hipotensi ortostatik (Varma., S, 2010).

\section{KESIMPULAN}

Terdapat 153 pasien geriatri di RSUD Panembahan Senopati Bantul yang masuk dalam kriteria inklusi dan 85 pasien $(55,6 \%)$ teridentifikasi Potentially Inappropiate Medications (PIMs). Potentially Inappropiate Medications yang termasuk pada kategori obat yang digunakan dengan hati-hati pada pasien geriatri persentase terbanyak yaitu furosemid sebanyak 37 penggunaan $(71.2 \%)$ diikuti dengan manitol $(13,5 \%)$, klorpromazin $(5,8 \%)$, haloperidol $(3,8 \%)$, sedangkan spironolakton, fluoxetine dan amitriptilin masingmasing adalah $1.9 \%$. 
DAFTAR PUSTAKA

American Geriatrics Society, 2015, American Geriatrics Society 2015 updated beers criteria for potentially inappropriate medication use in older adults. Journal of the American Geriatrics Society, 63(11), 2227-2246.

Anjum, S. M., Jacob, C., \& Benchamin, A., 2017, A Prospective Study on Geriatric Prescribing Pattern and Medication Adherence in a Tertiary Care Hospital, Asian Journal of Pharmaceutical and Clinical Research, 10, 220-225.

AS, A. N. M. S., Darmawan, E., \& Mustofa, M., 2015, Penggunaan Potentially Inappropriate Medications (PIMs) pada pasien geriatri rawat inap osteoarthritis di RS PKU Muhammadiyah Yogyakarta. Pharmaciana, 5(1): 77-84.

Astutik, W., \& Hasmono, D., 2013, Penggunaan Obat Golongan Diuretik Pada Pasien Stroke Iskemik Di Instalasi Rawat Inap RSU DR. Saiful Anwar Malang. Media Farmasi, 10(2): 84-93.

Burton, LA., Sumukadas, D., Witham M., Struthers, AD., 2013, Effect of Spironolactone on Physical Performance in Older People with Self-Reported Physical Disability, The American Journal of Medicine, 126(7) : 590-597.

Departemen Kesehatan Republik Indonesia. 2006. Pharmaceutical Care untuk Penyakit Hipertensi. Jakarta.

Dinsdale, C., Wani, M., teward, J., O’Mahony, MS, 2013, Tolerability of Spironolactone as Adjunctive Treatment fro Heart Failure in Patient Over 75 Years of Age, http://academic.oup.com/ageing/article-abstract/34/4/395/10527byguest,diakses pada 18 Mei 2018.

Endres, H. G., Kaufmann-Kolle, P., Steeb, V., Bauer, E., Böttner, C., \& Thürmann, P., 2016, Association between potentially inappropriate medication (PIM) use and risk of hospitalization in older adults: an observational study based on routine data comparing PIM use with use of PIM alternatives. PLoS one, 11(2): 1-15.

Fatimah, 2010, Merawat Manusia Lanjut Usia Suatu Pendekatan Proses Keperawatan Gerontik. Jakarta : Trans Info Media.

Ginsberg, M.D, 2008, Neuroprotection for ischemic stroke: past, present and future, NIH Journal, 55(3):363-389.

Harugeri, A., Joseph, J., Parthasarathi, G., Ramesh, M., \& Guido, S., 2010, Potentially inappropriate medication use in elderly patients: a study of prevalence and predictors in two teaching hospitals. Journal of postgraduate medicine, 56(3): 186-191.

Herron, JW, Mitchell, A., 2018, Depresion and Antidepressant Prescribing in The Elderly, BCMJ, 53 (47) : 341-347. 
Hubrechts, KF., Gerhard, T., Crystal, S., Olfson, M., Avorn, J., Levin, R., Lucas J.A., Schneeweiss, 2012, Differential Risk od Death in Older Residents in Nursing Homes Prescribed Specific Antpsycotic Drugs : Population Based Cohort Study, BMJ , 344 : $1-12$.

Ikawati, Z., 2014. Farmakoterapi Penyakit Sistem Syaraf Pusat (1 ${ }^{\text {st }}$ ed), Cetakan V, 104 151, Bursa Ilmu, Yogyakarta.

Kementerian Kesehatan Republik Indonesia, 2018, Hasil Utama Riskesdas 2018,diakses pada tanggal 2 Mei 2019, http://www.depkes.go.id/resources/download/infoterkini/hasil-riskesdas-2018.pdf.

Majid, A, 2014, Review Article : Neuroprotection in Stroke : Past, Present, and Future, International Scholarly Research Notices Neurology,1-17.

Nijboer, H., Lefeber, G., McLullich, A., Munster, B, 2016, Haloperidol Use Among Elderly Patients Undergoing Syrgery : A Retrospective 1-Year Study in a Hospital Population. Drug-Real World Outcomes, 11: 83-88.

Pionas, 2018, Manitol, Diakses 28 Mei 2018, dari http://pionas.pom.go.id/ioni/bab-2sistem-kardiovaskuler-0/25-diuretika/254-diuretika-osmotik

Rahajeng, B., 2007, Drug-Related Problems Pada Penatalaksanaan Pasien Stroke Rawat Inap di RSAL Dr. Ramelan Surabaya Periode 1 September - 31 Oktober 2006, Tesis, Sekolah Pascasarjana Universitas Gadjah Mada, Yogyakarta.

Shawkat, H., Westwood, M. M., \& Mortimer, A., 2012, Mannitol: a review of its clinical uses. Continuing Education in Anaesthesia, Critical Care and Pain, 12(2), 82-85.

Varma, S, Sareen, H, Trivedi, J.K, 2010, The Geriatric Population and Psychiatric Medication, Mens Sana Monograph, 8 (1): 30-51.

Wiese, B, 2011, Geriatric Depression : The Use of Antidepressant in The Elderly, BCMJ, 53 (47) : 341-347. 